\author{
${ }^{\odot S}$. V. Khmil ${ }^{1,2}$, N. Ya. Chudiiovych ${ }^{1,2}$, A. S. Khmil Dosvald ${ }^{1,2}$ \\ ${ }^{1}$ I. Horbachevsky Ternopil National Medical University \\ ${ }^{2}$ Medical Center "Professor Stefan Khmil Clinic"

\section{PRP-THERAPY OF ENDOMETRIUM: THE LATEST METHODS IN THE FIELD OF ASSISTED REPRODUCTIVE TECHNOLOGIES}

Recently, the preparation of the endometrium for embryo transfer, namely the achievement of optimal thickness and receptivity of the endometrium, the prevention of unsuccessful attempts to implant embryos, is gaining more and more attention among doctors in the field of reproductive medicine. Since cryptocycles of embryo transfer preparation are often discontinued in the practice of a reproductive physician due to insufficient endometrial thickness, high doses of estrogen and negative IVF results provided the satisfactory condition of the endometrium on the day of transfer and quality of the embryos. The article briefly presents the views on the effectiveness of PRP therapy of the endometrium in the protocols of preparation for embryo transfer. The main mechanisms of the effect of platelet-rich blood plasma on the endometrium are elucidated. The positive effect of this technique on regeneration, increase in thickness and improvement of endometrial receptivity is proved.

Conclusion. PRP-therapy of the endometrium is a modern, affordable, effective and safe method of treatment of thin and damaged endometrium in reproductive medicine.

Key words: infertility; assisted reproductive technologies; in vitro fertilization; PRP-therapy; endometrium.

PRP-ТЕРАПИЯ ЭНДОМЕТРИЯ: НОВЕЙШАЯ МЕТОДИКА В ОБЛАСТИ ВСПОМОГАТЕЛЬНЫХ РЕПРОДУКТИВНЫХ ТЕХНОЛОГИЙ

В последнее время все большее внимание среди врачей в области репродуктологии приобретает подготовка эндометрия к эмбриотрансферу, а именно достижение оптимальной толщины и рецептивности эндометрия, предупреждение неудачных попыток имплантации эмбрионов. Поскольку очень часто в практике врача репродуктолога наблюдается отмена криоциклов подготовки к эмбриотрансферу в связи с недостаточной толщиной эндометрия при использовании высоких доз эстрогенов и негативные результаты ЭКО при удовлетворительном состоянии эндометрия в день переноса и качества эмбрионов. В статье кратко представлены взгляды на эффективность PRP-терапии эндометрия в протоколах подготовки к переносу эмбрионов. Освещены основные механизмы влияния обогащенной тромбоцитами плазмы крови на эндометрий. Доказано положительное влияние данной методики на регенерацию, увеличение толщины и улучшение рецептивности эндометрия.

Вывод. PRP-терапия эндометрия является современным, доступным, эфффективным и безопасным методом лечения тонкого и поврежденного эндометрия в репродуктологии.

Ключевые слова: бесплодие; вспомогательные репродуктивные технологии; экстракорпоральное оплодотворение; PRP-терапия; эндометрий.

PRP-TЕРАПІЯ ЕНДОМЕТРІЯ: НОВІТНЯ МЕТОДИКА В ГАЛУЗІ ДОПОМІЖНИХ РЕПРОДУКТИВНИХ ТЕХНОЛОГІЙ

Протягом останнього часу все більшої уваги серед лікарів у галузі репродуктології набуває підготовка ендометрія до ембріотрансферу, а саме досягнення оптимальної товщини та рецептивності ендометрія, попередження невдалих спроб імплантації ембріонів. Оскільки дуже часто у практиці лікаря репродуктолога спостерігається відміна кріоциклів підготовки до ембріотранссеру у зв'язку із недостатньою товщиною ендометрія при використанні високих доз естрогенів та негативні результати ЕКЗ за умови задовільного стану ендометрія на день переносу та якості ембріонів. У статті коротко представлено погляди на ефективність PRP-терапії ендометрія у протоколах підготовки до переносу ембріонів. Висвітлено основні механізми впливу збагаченої тромбоцитами плазми крові на ендометрій. Доведено позитивний вплив даної методики на регенерацію, збільшення товщини та покращення рецептивності ендометрія.

Висновок. PRP-терапія ендометрія є сучасним, доступним, ефективним та безпечним методом лікування тонкого та ушкодженого ендометрія у репродуктології.

Ключові слова: безпліддя; допоміжні репродуктивні технології; екстракорпоральне запліднення; PRP-терапія; ендометрій.

To date, the newest and most effective method of treating all forms of infertility is the use of assisted reproductive technologies. Assisted reproductive technologies are a system of techniques by which some or all stages of gamete preparation, fertilization process, development of embryos before their transfer to the uterine cavity occur outside the woman's body, ie "in vitro" [1]. In vitro fertilization (IVF) is one of the methods of assisted reproductive technologies, which is the most effective among all methods. In turn, IVF consists of several main stages: preparatory, controlled ovulatory stimulation, follicle puncture with oocyte aspiration, fertilization, cultivation and transfer of embryos into the uterine cavity with subsequent hormone replacement therapy $[2,3]$. Each of these stages plays an equally important role in the pregnancy process and requires an individual approach and management tactics in each individual clinical situation.

Recently, the preparation of the endometrium for embryo transfer, namely the achievement of optimal thickness and receptivity of the endometrium, the prevention of unsuccessful attempts to implant embryos, is gaining more 
and more attention among doctors in the field of reproductive medicine.

The endometrium is the inner mucous membrane of the body of the uterus that lines its cavity and consists of basal and functional layers and is a hormone-sensitive tissue. Under the action of sex hormones (estrogen and progesterone), the functional layer of the endometrium undergoes morphofunctional changes during the menstrual cycle, resulting in the onset of menstruation or pregnancy. Thus, the endometrium is the main structure in the implementation of embryo implantation and pregnancy [4], as its satisfactory morphofunctional state is the most important factor influencing the quality of implantation of a fertilized egg with subsequent progression of pregnancy [5].

It is known that preparation for embryo transfer in IVF programs occurs in both fresh and cryocycles, in the natural menstrual cycle or with the use of hormone replacement therapy [6]. According to modern researchers, better results are observed in cryocycles, due to higher rates of embryo implantation, clinical pregnancy and live birth rate, compared with embryo transfer in fresh cycles, which have significantly lower levels of these indicators, as a result of deterioration of receptive properties after three months conducted controlled ovulatory stimulation [7]. The advantages of this method are the ability to conservatively adjust the thickness and receptivity of the endometrium. However, often in the practice of reproductive physicians there is a cancellation of cryocycles of preparation for embryo transfer due to insufficient thickness of the endometrium (up to $7 \mathrm{~mm}$ ), when using high doses of estrogen [8] and negative results (repeated unsuccessful implantation of embryos) if the condition is satisfactory in a day of embryo transfer and quality, which requires the search for the latest methods in implementing the effectiveness of IVF cycles.

Plasma therapy, which has been widely used not only in the field of aesthetic medicine, but also in ophthalmology, trichology, orthopedics (in the treatment of joint diseases), and aesthetic organs of women) and in the field of ART (in women with thin or damaged endometrium, unsuccessful re-implantation of embryos and in women with low ovulatory reserve) deserves innovative and progressive methods to improve the quality characteristics of the endometrium in the protocols of preparation for embryo transfer $[9,10]$.

Plasmolifting, or PRP-therapy of the endometrium - is a method of introducing one's own platelet-enriched plasma into the uterine cavity [11]. It is absolutely safe for the patient without causing any allergic reactions or complications, because the autoplasma is introduced. The purpose of plasma therapy is to activate growth factors and stem cells. In general, the method of using own plasma in the field of platelet-enriched medicine dates back to the 1970s and became more popular in the 1990s [12].

Data on the impact of PRP therapy for the treatment of thin endometrium were first published in 2015 by Chang Y., Li J., Chen Y., Wei L et al. In the study, intrauterine plasma therapy was administered to five women with thin endometrium who had insufficient response to hormone replacement therapy in cryocycles in preparation for embryo transfer. The effectiveness of intrauterine plasmalifting was noted in all patients, but pregnancy was observed in four patients [13]. Subsequently, four more studies in which researchers concluded that $\mathrm{PRP}$ is an effective treatment for thin endometrium, obtained data on the positive effects of plasmalifting on increasing the thickness of the endometrium and improving the outcome of pregnancy. PRP therapy was also reported to improve the incidence of implantation, clinical pregnancy, and fertility in women with thin endometrium [11, $14,15,16]$.

Platelets are components of the blood that play a key role in the system of hemostasis and regeneration. Blood plates perform several basic functions in the body, including the formation of blood clots and the release of growth factors that affect regeneration. Platelet-rich blood plasma contains a large number of growth factors and cytokines, including vascular growth factor (VEGF), platelet-derived growth factor (PDGF), epidermal growth factor (EGF), transforming growth factor (TGF), connective tissue growth factor (CTGF), fibroblast growth (Bfgf), insulin-like growth factor (IGF-I) and adhesive proteins: fibronectin, fibrin, vitronectin, which have pronounced anti-inflammatory and regenerative properties [17]. The above growth factors stimulate stem cells to produce new host tissue as quickly as possible, which explains the effectiveness of this technique.

PDGF is a glycoprotein that occurs during platelet degranulation at the site of injury. The mechanism of action is the activation of cell membrane receptors on the target cell, which form high-energy phosphate bonds that activate signaling proteins to initiate the specific activity of target cells. These specific functions include mitogenesis, angiogenesis, and macrophage activation. TGF- $\beta$ is produced by platelets as well as macrophages and acts as an antiproliferative factor in normal epithelial cells. TGF- $\beta$ exhibits three main types of biological activity: it inhibits the proliferation of most cells, but can stimulate the growth of some mesenchymal cells; has an immunosuppressive effect and enhances the formation of the intercellular matrix. The target cells for TGF- $\beta$ are fibroblasts, brain stem cells, and osteoblast progenitor cells. They participate in inflammatory reactions and wound healing. VEGF, known as vascular permeability factor, is a signaling protein produced by cells that stimulates vasculogenesis and angiogenesis. EGF is a growth factor that stimulates cell growth, proliferation and differentiation by binding to the EGFR receptor [18].

Published data suggest that the use of PRP therapy improves the regenerative properties of the endometrium in an animal model (studies in female rats) in which ethanol damaged the uterine cavity [19].

Before plasmolifting, each patient, both in gynecology and in the practice of a reproductive doctor, must undergo a mandatory gynecological examination and consultation with a physician in order to exclude contraindications to the use of this treatment. The patient must also undergo mandatory laboratory tests (general blood test, coagulogram, biochemical blood test, blood type and rhesus factor, blood test for RW, HIV, HCV, HbsAg).

The main contraindications to this procedure are [18]:

- Acute infectious diseases;

- Rising body temperature on the eve of the procedure;

- Hemodynamic instability;

- Platelet dysfunction syndrome;

- Viral hepatitis, AIDS, syphilis;

- History of cancer;

- Autoimmune diseases;

- Allergic reactions to anticoagulants; 
- Anemia;

- Low platelet count (less than 100 thousand/ $\mu$ l);

- Systemic use of glucocorticoids (within 2 weeks);

- Use of anticoagulants;

- Immunosuppressive states;

- Violation of the coagulating properties of blood;

- Mental disorders.

Preparing for PRP

In patients on day 9-10 of hormone replacement therapy, about $15-20 \mathrm{ml}$ of fresh whole blood is taken from a peripheral vein in a special tube with anticoagulant solution (ACD-A). Then the tubes are placed in a centrifuge, where blood samples are prepared for several minutes. Then 1.0-1.5 $\mathrm{ml}$ of the obtained plasma using a special catheter (COOK) slowly in the office, after pre-treatment of the vagina with antiseptic solutions, is injected into the uterine cavity of the woman. After the procedure, the woman is offered to lie down for 10 minutes. After 48 hours, ultrasound monitoring is performed to measure the thickness of the endometrium and decide whether to repeat the plasmalifting procedure [20].

The endometrial plasmolifting procedure can also be performed by office hysteroscopy using a puncture needle and the introduction of a small amount of platelet-enriched plasma of the patient's blood into the endometrium, but this technique is used in preparation for cryopreservation.

In a study by Yu. P. Boposlav and others (2016), patients with infertility were divided into two groups: the main group - 31 women and 30 women who were in the comparison group, another 30 healthy women who had been planning a pregnancy were in the control group. All women were treated for infertility by IVF. All patients received drug treatment according to the selected superovulation stimulation protocol. Women in the main group were injected with autoplasma prepared by the technology of MD R. R. Akhmerov and PhD R. F. Zarudiia (8 $\mathrm{ml}$ of whole blood was taken in a test tube Plasmolifting ${ }^{\mathrm{TM}}$, which was centrifuged for 5 minutes at $3000 \mathrm{rpm}$, then under aseptic conditions under application anesthesia $2 \mathrm{ml}$ of plasma was injected intrauterinely and 1.5 $\mathrm{ml}$ paracervically), the procedure was performed three times on day 20-22 of the previous menstrual cycle, in the cycle of stimulation for 5-7 and 12-14 days. The effectiveness of plasma therapy using PlasmoliftingTM tubes was proven. In women of the main group, the thickness of the endometrium, the number of antral, preovulatory follicles and the number of embryos were higher than in the comparison group. The incidence of pregnancy in the main group was $10 \%$ higher than in the comparison group, which confirms the positive effect of plasmalifting on the treatment of infertility in women by IVF. Its high efficiency and safety were highlighted [21].

In the work by L. Aghajanova et al. (2018) the study was conducted among 12 patients with moderate-severe Asherman's syndrome (5 patients - control group, 7 patients - study group). In the control group, Asherman's syndrome was caused by vacuum aspiration and uterine curettage, and in the study group - due to curettage in miscarriage or missed miscarriage, postpartum curettage and myomectomy. Women after hysteroscopy in the study group underwent intrauterine infusion of PRP, and in the control group - phys. solution. Women after hysteroscopy in the study group underwent intrauterine infusion of PRP, and in the control group - sodium chloride. Endometrial thickness, menstrual blood volume before and for 2 weeks after therapy were examined. There was no difference between the initial thickness of the endometrium, but after PRP there was an increase in its thickness. Three cases of clinical pregnancy were observed in the study group, and two in the control group. Thus, the paper presents data that PRP is a possible and promising method of treatment of Asherman's syndrome. This technique is easily tolerated by patients and is a much more effective method in the treatment of endometrial thickness compared to standard medical or surgical treatment of Asherman's syndrome [22].

Y. Chang, J. Li, X. Li et al. in 2017 conducted a study and noted that PRP plays an important role in promoting endometrial proliferation, improving the frequency of embryo implantation and the incidence of clinical pregnancy in women with thin endometrium [23].

O. Obidniak et al. (2017) in their work point to the effectiveness of intrauterine perfusion with autologous platelet-rich PRP plasma, which is considered a promising, safe and cost-effective method of therapy for patients with repeated unsuccessful embryo implants. Because there was a greater thickness of the endometrium, a higher frequency of embryo implantation and the onset of clinical pregnancy among women who underwent PRP ( $n-45)$ compared with the group of women who did not undergo plasmolifting ( $n$ 45 ), and proved that the PRP procedure does not affect the level of pregnancy loss [24].

Instead, in their work, F. Dieamant, L. D. Vagnini, J. B. Oliveira et al. (2019) did not note a significant difference in the frequency of pregnancy between the two groups (study group, whom in the protocols of preparation for ET performed PRP of the endometrium and subcutaneous administration of granulocyte colony-stimulating factor; control group - did not undergo the above procedures) [25].

The work of A. Allahveisi, F. Seyedoshohadaei, M. Rezaei et al. (2020) also did not report the effectiveness of PRP endometrial therapy in patients in cryoprotocol and failed IVF attempts in the past. Because the frequency of biochemical and clinical pregnancies did not differ between the study and control groups [20].

Numerous studies highlighted the relationship between PRP and female fertility. Studies show that intrauterine administration of platelet-rich blood plasma plays an important role in the preparation of patients with thin, damaged endometrium and failed implants in the past for embryo transfer; affects the effectiveness of IVF results, in turn has pronounced regenerative properties, increases the thickness and improves the receptivity of the endometrium, which increases the level of implantation and the frequency of clinical pregnancy. Today, there is much debate about the mechanism of its effect on a woman's reproductive system and the choice of the optimal method of PRP preparation (there are various techniques that include different blood sample preparation, amount of plasma injected, methods and days of administration) for comprehensive treatment of women with infertility associated with thin and damaged endometrium, which further requires more study.

CONCLUSIONS. PRP endometrial therapy is a modern, affordable, effective and safe method of treating thin and damaged endometrium in reproductive medicine. Its safety (does not cause allergic reactions, rejection, complications) is proved, as the patient's own plasma and efficiency are introduced (positive effect on regeneration, increase in thick- 
ness and improvement of endometrial receptivity, increase in pregnancy in IVF programs).

PROSPECTS OF FURTHER RESEARCH. Conducting a clinical study among women with a history of failed IVF to

\section{LITERATURE}

1. Історія впровадження допоміжних репродуктивних технологій при лікуванні безпліддя на Буковині / Т. А. Юзько, О.М.Юзько, А. Б. Жебчук [та ін.] // Буковинський медичний вісник. - 2014. - № 1 (69). - С. 229-231.

2. Farquhar C. Assisted reproductive technology: an overview of Cochrane Reviews / C. Farquhar, J. Marjoribanks // Cochrane Database Syst Rev. - 2018. - No. 8. DOI: 10.1002/14651858. CD010537.pub5.

3. Петрова Е. В. Основные этапы преодоления бесплодия с использованием программы вспомогательных репродуктивных технологий и ее модисрикаций / Е. В. Петрова, С. И. Михалевич // Медицинские новости. - 2012. № 2. - C. 45-49.

4. Чорненька Г. М. Морфологічні особливості ендометрія у жінок репродуктивного віку: аналіз морфометричних показників / Г.М.Чорненька, М.В.Логаш // Здобутки клінічної і експериментальної медицини. - 2018. - № 3. - С. 146-150.

5. Таравнех Д. Ш. Особливості структури і функції ендометрія у пацієнток з тромбофілією і невдалими спробами екстракорпорального запліднення в анамнезі / Д. Ш. Таравнех // Медицина сьогодні і завтра. - 2015. - № 4 (69). - С. 96-101.

6. Паращук В. Ю. Эффрективность разных протоколов подготовки эндометрия при переносе витрифицированных/ отогретых эмбрионов / В. Ю. Паращук, А. С. Луцкий, Н. Г. Грищенко // Здоровье женщины. - 2017. - № 2 (118) - С. 30-32.

7. Fresh versus frozen embryo transfer for full-term singleton birth: a retrospective cohort study / J. Zhang, M. Du, Zh. Li [et al.] // J. Ovarian Res. - 2018. - No. 11. - P. 59. DOI: 10.1186/ s13048-018-0432-x.

8. The incidence rate of unresponsive thin endometrium in frozen embryo transfer cycles: A case-series of therapy with granulocyte colony stimulating factor / Sh. Miralaei, M. Ashrafi, Ar. Arabipoor [et al.] // Int. J. Reprod. Biomed. (Yazd). - 2019. - No. 17 (12). - P. 923-928.

9. Autologous platelet-rich plasma eye drops in the treatment of recurrent corneal erosions / J. H. Lee, M. J. Kim, S. W. Ha, H. K. Kim // Korean J. Ophthalmol. - 2016. - No. 3. P. 101-107.

10. Platelet-rich plasma as a potential treatment for noncicatricial alopecias / G. Maria-Angeliki, K. Alexandros-Efstratios, R. Dimitris, K. Konstantinos // Int. J. Trichology. - 2015. No. 7. - P. 54-63.

11. Treatment of thin endometrium with autologous plateletrich plasma: a pilot study / Sh. Zadehmodarres, S. Salehpour, N. Saharkhiz, L. Nazari // JBRA Assist. Reprod. - 2017. - No. 21 (1). - P. 54-56.

12. Effect of autologous platelet-rich plasma treatment on refractory thin endometrium during the frozen embryo transfer cycle: A pilot study / H. Kim, J. E. Shin, H. S. Koo [et al.] //Front. Endocrinol. (Lausanne). - 2019. - No. 10. - P. 61.

\section{REFERENCES}

1. Yuzko, T.A., Yuzko, O.M., Zhebchuk, A.B., Zakharenko, L.V., Savchuk, L.T., Chemorkina, I.V., \& Vladychenko, K.A. (2014). Istoriia vprovadzhennia dopomizhnykh reproduktyvnykh study the effectiveness of PRP therapy of the endometrium. Because among modern domestic and foreign scientific works there are many contradictions regarding the effectiveness of this technique, which further requires more detailed research.

13. Autologous platelet-rich plasma promotes endometrial growth and improves pregnancy outcome during in vitro fertilization / Y. Chang, J. Li, Y. Chen [et al.] // Int. J. Clin. Exp. Med. 2015. - No. 8. - P. 1286-1290.

14. Use of platelet rich plasma in human infertility / G. V. L. Colombo, V. Fanton, D. Sosa [et al.] // J. Biol. Regul. Homeost. Agent. - 2017. - No. 31. - P. 179-182.

15. Platelet-rich plasma as an adjuvant in the endometrial preparation of patients with refractory endometrium / A. Molina, J. Sanchez, W. Sanchez, V. Vielma // JBRA Assist. Reprod. 2018. - No. 22. - P. 42-48.

16. Autologous intrauterine platelet-rich plasma instillation for suboptimal endometrium in frozen embryo transfer cycles: a pilot study / S. R. Tandulwadkar, M. V. Naralkar, A. D. Surana [et al.] // J. Hum. Reprod. Sci. - 2017. - No. 10. - P. 208-212.

17. Effect of autologous platelet-rich plasma transfusion in the treatment of infertile women with thin endometrium and its implications in IVF cycles: a literature review / A. Samy, A. M. Abbas, A. Elmoursi [et al.] // Middle East Fertil. Soc. J. - 2020. - Vol. 25 (5). - Access mode : https://doi.org/10.1186/ s43043-020-0019-5.

18. Jain N. K. Platelet-rich plasma: a healing virtuoso / N. K. Jain, M. Gulati // Blood Research. - 2016. - No. 51 (6). - P. 3-5.

19. Effects of autologous platelet-rich plasma on regeneration of damaged endometrium in female rats / H. Y. Jang, S. M. Myoung, J. M. Choe [et al.] // Yonsei Med. J. - 2017. No. 58. - P. 1195-1203.

20. The effect of platelet-rich plasma on the achievement of pregnancy during frozen embryo transfer in women with a history of failed implantation / Az. Allahveisi, F. Seyedoshohadaei, M. Rezaei [et al.] // Heliyon. - 2020. - No. 6. - E03577.

21. Наш опыт применения технологии «Плазмолисртинг» (Plasmolifting $^{\text {tm }}$ в в комплексном лечении бесплодия у женщин / ю. П. Богослав, И. Д. Гюльмамедова, Р. Р. Ахмеров, А. М. Яковец // Здоровье женщины. - 2016. - № 9 (115). - С. 152-154.

22. Autologous platelet rich plasma as a novel treatment for Asherman syndrome: results of a pilot randomized clinical trial / L. Aghajanova, J. Letourneau, M. I. Cedars, H. G. Huddleston // Fertil. Steril. - 2018. - N. 109 (3).

23. Platelet-rich plasma administration has benefit for infertile women with thin endometrium in frozen blastocyst-stage embryos transfer program / Y. Chang, J. Li, X. Li [et al.] // Fertil. Steril. - 2020. - No. 108 (3).

24. Randomized controlled trial evaluating efficacy of autologous platelet-rich plasma therapy for patients with recurrent implantation failure / D. Obidniak, A. Gzgzyan, A. Feoktistov, D. Niauri // Fertility and Sterility. - 2017. - No. 108 (3).

25. New therapeutic protocol for improvement of endometrial receptivity (PRIMER) for patients with recurrent implantation failure (RIF) - a pilot study / F. Dieamant, L. D. Vagnini, J. B. Oliveira [et al.] // Fertil. Steril. - 2019. - No. 110 (4). - P. 240-241.

tekhnolohii pry likuvanni bezliddia na Bukovyni [History of introduction of assisted reproductive technologies in the treatment of infertility in Bukovyna]. Bukovynskyi medychnyi 
visnyk - Bukovynian Medical Bulletin, 1 (69), 229-231 [in Ukrainian].

2. Farquhar, C., \& Marjoribanks, J. (2018). Assisted reproductive technology: an overview of Cochrane Reviews. Cochrane Database Syst. Rev., 8. DOI: 10.1002/14651858. CD010537.pub5.

3. Petrova, E.V., \& Mihalevich, S.I. (2012). Osnovnyye etapy preodoleniya besplodiya $s$ ispolzovaniem programmy vspomogatelnykh reproduktivnykh tehnologiy i ee modifikatsiy [The main stages of overcoming infertility using the program of assisted reproductive technologies and its modifications]. Meditsinskie novosti - Medical News, 2, 45-49 [in Russian].

4. Chornenka, G.M., \& Logash, M.V. (2018). Morfolohichni osoblyvosti endometriia u zhinok reproduktyvnoho viku: analiz morfometrychnyh pokaznykiv [Morphological features of the endometrium in women of reproductive age: analysis of morphometric parameters]. Zdobutky klinichnoi i eksperimentalno medytsyny - Achievements of Clinical and Experimental Medicine, 3, 146-150 [in Ukrainian].

5. Taravneh, D.Sh. (2015). Osoblyvosti struktury i funktsii endometriya u patsiientok $z$ trombofiliieiu i nevdalymy sprobamy ekstrakorporalnogo zaplidnennia $v$ anamnezi [Features of the structure and function of the endometrium in patients with a history of thrombophilia and unsuccessful attempts at in vitro fertilization]. Medytsyna sohodni i zavtra - Medicine Today and Tomorrow, 4 (69), 96-101 [in Ukrainian].

6. Paraschuk, V.Yu., Lutskiy, A.S., \& Grischenko, N.G. (2017). Effektivnost raznykh protokolov podgotovki endometriya pri perenose vitrifitsirovannyih/otogretyih embrionov [Effectiveness of different endometrial preparation protocols for the transfer of vitrified/warmed embryos]. Zdorovie zhenschiny Women's Health, 2 (118), 30-32 [in Russian].

7. Zhang J., Du M., Li Zh., Wang, L., Hu, J., Zhao, B., ..., \& Sun, L. (2018). Fresh versus frozen embryo transfer for full-term singleton birth: a retrospective cohort study. J. Ovarian. Res., 11, 59. DOI: 10.1186/s13048-018-0432-x.

8. Miralaei, Sh., Ashrafi, M., Arabipoor, Ar., Zolfaghari, Z., \& Taghvaei, S. (2019). The incidence rate of unresponsive thin endometrium in frozen embryo transfer cycles: A case-series of therapy with granulocyte colony stimulating factor. Int. J. Reprod. Biomed. (Yazd), 17 (12), 923-928.

9. Lee, J.H., Kim, M.J., Ha, S.W., \& Kim, H.K. (2016). Autologous platelet-rich plasma eye drops in the treatment of recurrent corneal erosions. Korean J. Ophthalmol., 3, 101-107.

10. Maria-Angeliki, G., Alexandros-Efstratios, K., Dimitris, R., \& Konstantinos, K. (2015). Platelet-rich plasma as a potential treatment for noncicatricial alopecias. Int. J. Trichology., 7, 54-63.

11. Zadehmodarres, Sh., Salehpour, S., Saharkhiz, N., \& Nazari, L. (2017). Treatment of thin endometrium with autologous platelet-rich plasma: a pilot study. JBRA Assist. Reprod., 21 (1), 54-56

12. Kim, H., Shin, J.E., Koo, H.S., Kwon, H., Choi, D.H., \& Kim, J.H. (2019). Effect of autologous platelet-rich plasma treatment on refractory thin endometrium during the frozen embryo transfer cycle: A pilot study. Front. Endocrinol. (Lausanne), 10, 61 .
13. Chang, Y., Li, J., Chen, Y., Wei, L., Yang, X., Shi, Y., \& Liang, X. (2015). Autologous platelet-rich plasma promotes endometrial growth and improves pregnancy outcome during in vitro fertilization. Int. J. Clin. Exp. Med., 8, 1286-1290.

14. Colombo, G.V.L., Fanton, V., Sosa D., Scholz, E.C., Lotti, J., Aragona, S.E., \& Lotti, T. (2017). Use of platelet rich plasma in human infertility. J. Biol. Regul. Homeost. Agent, 31, 179-182.

15. Molina, A., Sanchez, J., Sanchez, W., \& Vielma, V. (2018). Platelet-rich plasma as an adjuvant in the endometrial preparation of patients with refractory endometrium. JBRA Assist. Reprod, 22, 42-48.

16. Tandulwadkar, S.R., Naralkar, M.V., Surana, A.D., Selvakarthick, M., Kharat, A.H. (2017). Autologous intrauterine platelet-rich plasma instillation for suboptimal endometrium in frozen embryo transfer cycles: a pilot study. J. Hum. Reprod. Sci, 10, 208-212.

17. Samy, A., Abbas, A.M., Elmoursi, A., Elsayed, M., \& Hussein, R.S. (2020). Effect of autologous platelet-rich plasma transfusion in the treatment of infertile women with thin endometrium and its implications in IVF cycles: a literature review. Middle East Fertil Soc J., 25 (5). - Retrieved from: https://doi.org/10.1186/ s43043-020-0019-5.

18. Jain, N.K., \& Gulati, M. (2016). Platelet-rich plasma: a healing virtuoso. Blood Research, 51 (6), 3-5.

19. Jang, H.Y., Myoung, S.M., Choe, J.M., Kim, T., Cheon, Y.P., Kim, Y.M., \& Park, H. (2017). Effects of autologous platelet-rich plasma on regeneration of damaged endometrium in female rats. Yonsei Med. J., 58, 1195-1203.

20. Allahveisi, Az., Seyedoshohadaei, F., Rezaei, M., Bazrafshan, N., \& Rahimi, K. (2020). The effect of platelet-rich plasma on the achievement of pregnancy during frozen embryo transfer in women with a history of failed implantation. Heliyon, 6, E03577.

21. Bogoslav, Yu.P., Gyulmamedova, I.D., Ahmerov, R.R., \& Yakovets, A.M. (2016). Nash opyt primeneniya tehnologii "Plazmolifting" (Rlasmoliftingtm) v kompleksnom lechenii besplodiya $u$ zhenschin [Our experience of using Plasmolifting technology (Plasmoliftingtm) in the complex treatment of infertility in women]. Zdorovye zhenshchiny - Women's Health, 9 (115), 152-154 [in Russian].

22. Aghajanova, L., Letourneau, J., Cedars, M.I., \& Huddleston, H.G. (2018). Autologous platelet rich plasma as a novel treatment for Asherman syndrome: results of a pilot randomized clinical trial. Fertil. Steril., 109 (3).

23. Chang Y., Li, J., Li, X., Yang, X., \& Liang, X. (2020). Platelet-rich plasma administration has benefit for infertile women with thin endometrium in frozen blastocyst-stage embryos transfer program. Fertil. Steril., 108 (3).

24. Obidniak, D., Gzgzyan, A., Feoktistov, A., \& Niauri, D. (2017). Randomized controlled trial evaluating efficacy of autologous platelet-rich plasma therapy for patients with recurrent implantation failure. Fertil. Steril., 108 (3).

25. Dieamant, F., Vagnini, L.D., Oliveira, J.B., Mauri, A.L., Renzi, A., Petersen, B., ..., \& Franco, Jr. (2019). New therapeutic protocol for improvement of endometrial receptivity (PRIMER) for patients with recurrent implantation failure (RIF) - a pilot study. Fertil. Steril., 110 (4), 240-241.

Received 14.05.20 Accepted 10.06.20 Address for correspondence: chudiiovych.na@gmail.com 